\title{
Predicting the need for supplemental oxygen during airline flight in patients with chronic pulmonary disease: A comparison of predictive equations and altitude simulation
}

\author{
Ana C Bradi BSc ${ }^{1}$, Marie E Faughnan $\mathrm{MD}^{2}$, Matthew B Stanbrook MD PhD ${ }^{1}$, \\ Eva Deschenes-Leek RRT ${ }^{2}$, Kenneth R Chapman MD MSc ${ }^{1}$
}

\begin{abstract}
AC Bradi, ME Faughnan, MB Stanbrook, E Deschenes-Leek, KR Chapman. Predicting the need for supplemental oxygen during airline flight in patients with chronic pulmonary disease: A comparison of predictive equations and altitude simulation. Can Respir J 2009;16(4):119-124.
\end{abstract}

BACKGROUND: Patients with chronic pulmonary diseases are at increased risk of hypoxemia when travelling by air. Screening guidelines, predictive equations based on ground level measurements and altitude simulation laboratory procedures have been recommended for determining risk but have not been rigorously evaluated and compared.

OBJECTIVES: To determine the adequacy of screening recommendations that identify patients at risk of hypoxemia at altitude, to evaluate the specificity and sensitivity of published predictive equations, and to analyze other possible predictors of the need for in-flight oxygen.

METHODS: The charts of 27 consecutive eligible patients referred for hypoxia altitude simulation testing before flight were reviewed. Patients breathed a fraction of inspired oxygen of 0.15 for $20 \mathrm{~min}$. This patient population was compared with the screening recommendations made by six official bodies and compared the partial pressure of arterial oxygen $\left(\mathrm{PaO}_{2}\right)$ obtained during altitude simulation with the $\mathrm{PaO}_{2}$ predicted by 16 published predictive equations.

RESULTS: Of the 27 subjects, $25 \%$ to $33 \%$ who were predicted to maintain adequate oxygenation in flight by the British Thoracic Society, Aerospace Medical Association or American Thoracic Society guidelines became hypoxemic during altitude simulation. The 16 predictive equations were markedly inaccurate in predicting the $\mathrm{PaO}_{2}$ measured during altitude simulation; only one had a positive predictive value of greater than $30 \%$. Regression analysis identified $\mathrm{PaO}_{2}$ at ground level $(\mathrm{r}=0.50$; $\mathrm{P}=0.009)$, diffusion capacity $(\mathrm{r}=0.56 ; \mathrm{P}=0.05)$ and per cent forced expiratory volume in $1 \mathrm{~s}(\mathrm{r}=0.57 ; \mathrm{P}=0.009)$ as having predictive value for hypoxia at altitude.

CONCLUSIONS: Current screening recommendations for determining which patients require formal assessment of oxygen during flight are inadequate. Predictive equations based on sea level variables provide poor estimates of $\mathrm{PaO}_{2}$ measured during altitude simulation.

Key Words: Altitude; COPD; Flight; Hypoxemia; Hypoxia altitude simulation test; Normobaric challenge; Recommendations

The growing prevalence of chronic pulmonary disease 1 ensures that clinicians will increasingly be called on to evaluate their patients' fitness to travel by air. Travel by modern airliner exposes patients to the reduced ambient oxygen tensions equivalent to those experienced at $2438 \mathrm{~m}$ above sea level for several hours, which can cause significant hypoxemia in individuals with chronic lung disease.

In the physician's office, determining the impact of highaltitude exposure involves two steps. The first step is to screen

\section{Prédire la nécessité du recours à l'oxygène \\ d'appoint en vol chez des voyageurs souffrant de maladie pulmonaire chronique : Comparaison des équations prédictives et de la simulation d'altitude}

HISTORIQUE : Les patients qui souffrent de maladie pulmonaire chronique sont exposés à un risque accru d'hypoxémie lorsqu'ils prennent l'avion. Des lignes directrices en matière de dépistage, fondées sur des équations prédictives calculées à partir de mesures au sol et d'épreuves de simulation d'altitude en laboratoire, ont été recommandées pour évaluer le risque, mais n'ont pas fait l'objet de vérifications ni de comparaisons rigoureuses.

OBJECTIF : Déterminer la justesse des recommandations pour le dépistage du risque d'hypoxémie chez ces patients, évaluer la spécificité et la sensibilité des équations prédictives publiées et analyser d'autres facteurs permettant de prédire la nécessité d'administrer de l'oxygène durant le vol.

MÉTHODE : Les auteurs ont passé en revue les dossiers de 27 patients consécutifs admissibles, adressés pour épreuve de simulation d'hypoxémie en altitude avant une envolée. Les patients ont respiré une fraction d'oxygène inspiré de 0,15 pendant 20 minutes. Cette population de patients a servi de base de comparaison entre les recommandations de six instances officielles relativement au dépistage et a permis de comparer la pression partielle artérielle en oxygène $\left(\mathrm{PaO}_{2}\right)$ obtenue durant la simulation d'altitude aux prédictions de $\mathrm{PaO}_{2}$ calculées au moyen de 16 équations prédictives publiées.

RÉSULTATS : Parmi les 27 sujets, de $25 \%$ à $33 \%$ chez qui on avait prédit le maintien d'une oxygénation adéquate en vol selon les lignes directrices de la British Thoracic Society, de l'Aerospace Medical Association ou de l'American Thoracic Society ont développé une hypoxémie durant la simulation d'altitude. Les 16 équations prédictives se sont révélées très imprécises pour ce qui est de prévoir la $\mathrm{PaO}_{2}$ mesurée durant la simulation d'altitude. Une seule a présenté une valeur prédictive positive supérieure à $30 \%$. L'analyse de régression a permis d'identifier la $\mathrm{PaO}_{2}$ au sol $(\mathrm{r}=0,50 ; \mathrm{P}=0,009)$, la capacité de diffusion $(\mathrm{r}=0,56 ; \mathrm{P}=0,05)$ et le pourcentage du volume expiratoire maxime en une seconde $(\mathrm{r}=0,57 ; \mathrm{P}=0,009)$ comme des éléments dotés d une valeur prédictive pour ce qui est de prévoir l'hypoxémie en altitude.

CONCLUSION : Les recommandations actuelles en matière de dépistage des patients susceptibles de nécessiter une évaluation formelle de leurs besoins en oxygène en vol sont inadéquates. Les équations prédictives établies à partir de variables mesurées au niveau de la mer donnent des estimations erronées de la $\mathrm{PaO}_{2}$ mesurée lors de la simulation d'altitude.

${ }^{1}$ Asthma and Airway Centre, University Health Network, Toronto Western Hospital; ${ }^{2}$ Division of Respirology, Department of Medicine,

St Michael's Hospital, University of Toronto, Toronto, Ontario

Correspondence and reprints: Dr Kenneth R Chapman, Asthma and Airway Centre, University Health Network, Toronto Western Hospital, Room

7-451 East Wing, 399 Bathurst St, Toronto, Ontario M5T 2S8. Telephone 416-603-5499, fax 416-603-3456, e-mail kchapman@ca.inter.net Accepted for publication December 5, 2008 
patients at risk (1-5). The BTS recommends a hypoxia altitude simulation test (HAST) for patients with a baseline saturation of peripheral oxygen $\left(\mathrm{SpO}_{2}\right)$ of between $92 \%$ and $95 \%$, and an additional risk factor (1). Values outside of this range imply safety or the need for supplemental oxygen. The ATS/ERS guidelines and VA guidelines recommend a HAST for chronic obstructive pulmonary disease (COPD) patients with comorbidities, previous in-flight symptoms, recent exacerbation(s), hypoventilation on oxygen administration or borderline estimates from a regression equation $(2,5)$. The AMA and CTS consider a partial pressure of arterial oxygen at ground level $\left(\mathrm{PaO}_{2 \mathrm{gr}}\right)$ of less than $70 \mathrm{mmHg}$ to be an indication of a patient's need for altitude simulation $(3,4)$.

The clinician's second task is to decide whether the identified patients are able to tolerate the conditions of air travel. Here also, there are discrepant guidelines concerning the choice of test and how to interpret the results. The HAST artificially reduces inspired oxygen to similar levels experienced at $2438 \mathrm{~m}$ for $20 \mathrm{~min}$ by either giving a fraction of inspired oxygen of 0.15 or by reducing atmospheric pressure to 565 Torr $(75 \mathrm{KPa})$ in a hypobaric chamber; both methods are considered to be equivalent $(6,7)$. The expected $\mathrm{PaO}_{2}$ at altitude $\left(\mathrm{PaO}_{2 a l t}\right)$ is then determined from measurements of arterial blood gases (ABGs). The HAST is considered to be the 'gold standard'; however, opinions differ as to whether a $\mathrm{PaO}_{2}$ of $55 \mathrm{mmHg}$ or less (AMA) or $50 \mathrm{mmHg}$ (ATS, ERS and VA) warrants the prescription of oxygen for flight. The HAST simulates the maximum drop in pressure expected during air travel, and has been demonstrated to produce oxygenation comparable with that observed during actual air travel (7-9).

Several investigators have developed predictive equations that estimate $\mathrm{PaO}_{2 \text { alt }}$ using measurements made at sea level $(6,10-15) ; \mathrm{PaO}_{2 \mathrm{gr}}$ appears in all equations. Other variables include cabin altitude, inspired oxygen pressure at altitude, partial pressure of arterial carbon dioxide $\left(\mathrm{PaCO}_{2}\right)$ at sea level, health status, forced expiratory volume in $1 \mathrm{~s}\left(\mathrm{FEV}_{1}\right)$ and forced vital capacity (FVC). Guideline documents refer to equations as either a screening tool for recommending a HAST (ATS, ERS), or a replacement for HAST when it is unavailable (BTS, VA).

Finally, some airline medical departments and the AMA recommend the $50 \mathrm{~m}$ walk test as a sufficient estimate of fitness to fly $(1,4)$.

The current study aimed to evaluate the latter methods of determining fitness to fly in patients with chronic lung disease. We propose that predictive equations and the $50 \mathrm{~m}$ walk test must be both highly specific and sensitive to be useful clinical tools. Our objectives were to determine the adequacy of screening recommendations at identifying patients at risk of hypoxemia at altitude, to evaluate the specificity and sensitivity of published predictive equations compared with the HAST, and to analyze other possible predictors of the need for in-flight oxygen.

\section{METHODS}

Charts were reviewed at two university affiliated teaching hospital pulmonary function laboratories that performed altitude simulation testing. Consecutive patients who were not on supplemental oxygen were tested during a 10-month period. The study was approved by the Research Ethics Board of the University Health Network, Toronto, Ontario.
Altitude simulation was performed as previously described (11). For altitude simulation, patients inhaled a fraction of inspired oxygen of 0.15 via a nonrebreathing mask for $20 \mathrm{~min}$ with concurrent pulse oximetry. Measurements of ABGs were taken from the radial artery after subjects had inhaled the hypoxic mixture for $20 \mathrm{~min}$ whereupon they recovered with supplemental oxygen. Only one centre took baseline ABGs for the HAST. For the other patients, baseline ABGs were taken within three months of the HAST, from outpatient visits only.

$\mathrm{PaO}_{2 \text { alt }}$ estimates derived from 16 predictive equations (Table 1) were compared with the $\mathrm{PaO}_{2 \text { alt }}$ measured during the HAST and each equation was evaluated for sensitivity, specificity, positive and negative predictive value, positive and negative likelihood ratio and accuracy that considered $\mathrm{a} \mathrm{Pa}_{2 \text { alt }}$ of $50 \mathrm{mmHg}$ or less a positive result.

If patients in our population did not meet the criteria specified by the equation's authors, the equation was evaluated in the subset of our population who did meet the criteria. The following inclusion criteria relate to equations 3, 4, 5, 15 and 16 respectively (Table 1): $\mathrm{FEV}_{1}$ less than $80 \%$ of predicted and $\mathrm{FEV}_{1} / \mathrm{FVC}$ ratio less than 70\%; COPD; $\mathrm{PaO}_{2}$ greater than $70 \mathrm{mmHg}, \mathrm{SpO}_{2}$ greater than or equal to $95 \%$; and $\mathrm{FEV}_{1}$ greater than $60 \%$ of predicted.

Data from a 6 min walk test was obtained within three months of the HAST to evaluate the airline criteria of a successful $50 \mathrm{~m}$ walk for determining fitness to fly. The inclusiveness of the various guidelines was evaluated by determining how many patients would not have been tested according to each guideline, and of those, how many were hypoxemic after undergoing a HAST.

Receiver operating characteristic (ROC) curves of both the $\mathrm{PaO}_{2}$ and the $\mathrm{SpO}_{2}$ at sea level were plotted to evaluate fitness to fly cut-off values. Finally, a multiple stepwise regression analysis was performed to determine if any values of $\mathrm{FEV}_{1}$, $\mathrm{FVC}, \mathrm{FEV}_{1} / \mathrm{FVC}$, residual volume or diffusion capacity (DLCO) correlated strongly with $\mathrm{PaO}_{2}$ after HAST. Results were considered significant at $\mathrm{P}<0.05$.

\section{RESULTS}

The patients $(\mathrm{n}=27)$ had typical chronic lung disease of moderate severity. Three patients had cystic fibrosis, 22 had COPD, and two had cystic fibrosis and COPD. Demographic data are presented in Table 2. After a HAST, four patients had $\mathrm{PaO}_{2}$ value of less than $50 \mathrm{mmHg}$ and six had values of between $55 \mathrm{mmHg}$ and $50 \mathrm{mmHg}$. The $50 \mathrm{mmHg}$ cut-off was used for the purpose of the present paper; however, all 10 of these patients were advised to consider in-flight supplemental oxygen.

Table 3 presents an evaluation of each equation that was tested. Equations showed better or equivalent results when tested on their intended population than with the entire sample set. Equations 1 to 9 underestimated the $\mathrm{PaO}_{2 \text { alt }}$, leading to high sensitivity but low specificity. In contrast, equations 15 and 16 overestimated the $\mathrm{PaO}_{2 \text { alt }}$, resulting in high specificity but low sensitivity. These two equations did not identify any patients as needing in-flight oxygen. Equations 10 and 14 were low in both sensitivity and specificity.

The 11 patients who performed a 6 min walk test covered (mean $\pm \mathrm{SD}$ ) $359 \pm 101 \mathrm{~m}$, all passing the airline requirements for fitness to fly. Evaluations based on $\mathrm{SpO}_{2}$ during the $6 \mathrm{~min}$ 
TABLE 1

\section{Predictive equations evaluated}

\begin{tabular}{|c|c|c|}
\hline \multicolumn{2}{|c|}{ Equation } & \multirow{2}{*}{$\begin{array}{l}\text { Author (reference) } \\
\text { Dillard et al (10) }\end{array}$} \\
\hline 1 & $\mathrm{PaO}_{2 \text { alt }}=0.410\left(\mathrm{PaO}_{2 \mathrm{gr}}\right)+17.652$ & \\
\hline 3 & $\mathrm{PaO}_{2 \text { alt }}=22.8-2.74^{\star} \mathrm{feet}+0.68^{*} \mathrm{PaO}_{2 \mathrm{gr}}$ & Gong et al (11) \\
\hline 5 & $\mathrm{PaO}_{2} \mathrm{FIO}_{2} 0.15=\mathrm{PaO}_{2} \mathrm{FIO}_{2} 0.21^{*} 0.54+4.7$ & Seccombe et al (13) \\
\hline 6 & $\mathrm{PaO}_{2 \text { alt }}=1.59+0.98^{*} \mathrm{PaO}_{2 \mathrm{gr}}+0.0031^{*} \mathrm{Alt}-0.000061^{*} \mathrm{PaO}_{2 \mathrm{gr}}{ }^{*} \mathrm{Alt}-0.000065^{*} \mathrm{PCO}_{2 \mathrm{gr}}{ }^{*} \mathrm{Alt}+0.000000092^{*} \mathrm{Alt}^{2}$ & Muhm (14) \\
\hline 9 & $\mathrm{PaO}_{\text {2alt }}=10.61+0.87^{*} \mathrm{PaO}_{2 \mathrm{gr}}+0.0004^{*} \mathrm{Alt}-0.000033^{*} \mathrm{PaO}_{2 \mathrm{gr}}{ }^{*} \mathrm{Alt}-0.000033^{*} \mathrm{PCO}_{2 \mathrm{gr}}{ }^{*} \mathrm{Alt}+0.000027^{*} \mathrm{Alt}{ }^{*} \mathrm{HS}$ & Muhm (14) \\
\hline 10 & $\mathrm{PaO}_{2 \text { alt }}=0.519 \times \mathrm{PaO}_{2 \mathrm{gr}}+11.855 \times \mathrm{FEV}_{1}(\mathrm{~L})-1.760$ & Dillard et al (10) \\
\hline 11 & $\mathrm{PaO}_{2 \text { alt }}=0.453 \times \mathrm{PaO}_{2 \mathrm{gr}}+0.386 \times \mathrm{FEV}_{1}(\%$ predicted $)+2.44$ & Dillard et al (10) \\
\hline 12 & $\mathrm{PaO}_{2 \text { alt }}=0.294\left(\mathrm{PaO}_{2 \mathrm{gr}}\right)+0.086\left(\mathrm{FEV}_{1} \%\right)+23.211$ & Dillard et al (6) \\
\hline 13 & $\mathrm{PaO}_{\text {2alt }}=0.245\left(\mathrm{PaO}_{2 \mathrm{gr}}\right)+0.171\left(\mathrm{FEV}_{1} / \mathrm{FVC} \%\right)+21.028$ & Dillard et al (6) \\
\hline
\end{tabular}

The equation number is used to identify each equation within the text. Alt Altitude; cabin ${ }_{\text {alt }}$ Cabin pressure at altitude; HS Pulmonary health status: 1 = normal, -1 = chronic obstructive pulmonary disease; FEV ${ }_{1}$ Forced expiratory volume in $1 \mathrm{~s} ; \mathrm{FIO}_{2}$ Fraction of inspired oxygen; FVC Forced vital capacity; PaO ${ }_{2 a l t}$ Partial pressure of arterial oxygen at altitude; $\mathrm{PCO}_{2}$ Partial pressure of carbon dioxide at sea level; $\mathrm{PIO}_{2 \text { alt }}$ Inspired oxygen pressure at altitude; PaO 2 r $P$ artial pressure of arterial oxygen at ground level

walk test did not improve this test's predictive value. Five patients had an $\mathrm{SpO}_{2}$ below 85\% while walking, but of these, only two were identified by the HAST as needing supplemental in-flight oxygen. One interesting trend was that the four patients for whom the HAST recommended supplemental oxygen walked the shortest distance in the patient population (330 $\mathrm{m}$ or less in $6 \mathrm{~min}$ ).

Of the 12 patients who the BTS considered fit to fly $\left(\mathrm{SpO}_{2}\right.$ greater than $95 \%$ ), three had a $\mathrm{PaO}_{2}$ of less than $50 \mathrm{mmHg}$ after the HAST and one had a $\mathrm{PaO}_{2}$ of $52 \mathrm{mmHg}$. Four of the $16 \mathrm{sub}-$ jects presumed fit to fly by the AMA $\left(\mathrm{PaO}_{2 \text { gr }}\right.$ of $70 \mathrm{mmHg}$ or higher) also benefited from the HAST $\left(\mathrm{PaO}_{2 \text { alt }} 55 \mathrm{mmHg}\right.$ or less), with one below $50 \mathrm{mmHg}$. Thus, $25 \%$ to $33 \%$ of the population presumed fit to fly required further investigation. Figure 1 shows the drop in $\mathrm{PaO}_{2}$ experienced by each of these six patients between room air and the HAST. Diagnosis of these patients revealed that three had COPD, two had cystic fibrosis and one patient had both. The drops in $\mathrm{PaO}_{2}$ observed in the two cystic fibrosis patients were not distinguishable from those of the three COPD patients.

ROC curves are shown in Figure 2. Baseline $\mathrm{PaO}_{2}$, as validated against HAST outcome, gave an area under the ROC curve of $0.696 \pm 0.095(\mathrm{P}<0.13)$ and suggested that the cut-off yielding greatest accuracy was a $\mathrm{PaO}_{2}$ of $72 \mathrm{mmHg}$ or less, at which point sensitivity was 1.00 and specificity was 0.61 . Baseline $\mathrm{SpO}_{2}$ as validated against HAST outcome, gave an area under the ROC curve of $0.402 \pm 0.112(\mathrm{P}<0.55)$ and suggested a cut-off value for greatest accuracy of $96 \%$, at which point sensitivity was 1.00 and specificity was 0.74 . Each equation was also subjected to ROC analysis in comparison with the HAST results (Table 3). Based on the area under the ROC curve, equation 3 was the most accurate predictor evaluated but had poor overall predictive characteristics.

Regression analysis determined three variables that correlated with the ratio of $\mathrm{PaO}_{2 \text { alt }}$ to $\mathrm{PaO}_{2 \mathrm{gr}}(\mathrm{r}=0.45 ; \mathrm{P}<0.009)$, DLCO

\section{TABLE 2}

\section{Demographic data}

\begin{tabular}{|c|c|c|}
\hline Characteristic & Mean \pm SD & $\mathbf{n}$ \\
\hline Age, years & $64 \pm 18$ & 27 \\
\hline Men, \% & 57 & 27 \\
\hline Height, cm & $163 \pm 10$ & 25 \\
\hline Weight, kg & $70 \pm 16$ & 25 \\
\hline Chronic obstructive pulmonary disease, $\%$ & 93 & 27 \\
\hline FVC, L & $2.48 \pm 1.02$ & 20 \\
\hline FVC, \% predicted & $76 \pm 25$ & 20 \\
\hline $\mathrm{FEV}_{1}, \mathrm{~L}$ & $1.41 \pm 0.71$ & 20 \\
\hline $\mathrm{FEV}_{1}, \%$ predicted & $58 \pm 22$ & 20 \\
\hline $\mathrm{FEV}_{1} / \mathrm{FVC}$ & $58 \pm 17$ & 20 \\
\hline $\mathrm{FEV}_{1} / \mathrm{FVC}, \%$ predicted & $79 \pm 23$ & 20 \\
\hline Residual volume, L & $2.01 \pm 1.16$ & 14 \\
\hline Diffusion capacity, $\mathrm{mL} / \mathrm{min} / \mathrm{mmHg}$ & $12.19 \pm 5.73$ & 13 \\
\hline \multicolumn{3}{|l|}{ Baseline blood gases } \\
\hline $\mathrm{SpO}_{2}, \%$ & $95 \pm 3$ & 27 \\
\hline $\mathrm{PaCO}_{2}, \mathrm{mmHg}$ & $38 \pm 5$ & 27 \\
\hline $\mathrm{PaO}_{2}, \mathrm{mmHg}$ & $75 \pm 10$ & 27 \\
\hline \multicolumn{3}{|l|}{ Post-HAST blood gases } \\
\hline $\mathrm{SpO}_{2}, \%$ & $89 \pm 3$ & 27 \\
\hline $\mathrm{PCO}_{2}, \mathrm{mmHg}$ & $37 \pm 4$ & 27 \\
\hline $\mathrm{PO}_{2}, \mathrm{mmHg}$ & $58 \pm 7$ & 27 \\
\hline
\end{tabular}

FEV 1 Forced expiratory volume in $1 \mathrm{~s}$; FVC Forced vital capacity; HAST Hypoxia altitude simulation test; $\mathrm{PaCO}_{2}$ Partial pressure of arterial carbon dioxide at sea level; $\mathrm{PCO}_{2}$ Partial pressure of carbon dioxide; $\mathrm{PaO}_{2}$ Partial pressure of arterial oxygen; $\mathrm{PO}_{2}$ Partial pressure of oxygen; $\mathrm{SpO}_{2}$ Baseline saturation of peripheral oxygen

$(\mathrm{r}=0.56 ; \mathrm{P}<0.05)$ and $\mathrm{FEV}_{1} \%$ predicted $(\mathrm{r}=0.57 ; \mathrm{P}<0.009)$. All other variables tested (age, $\mathrm{FVC}, \mathrm{FEV}_{1} / \mathrm{FVC}$ and residual volume) showed no statistically significant correlations with $\mathrm{PaO}_{2 \text { alt }}$. 
TABLE 3

Equation and $50 \mathrm{~m}$ walk test evaluation

\begin{tabular}{|c|c|c|c|c|c|c|c|c|c|}
\hline Equation & Sensitivity & Specificity & $\begin{array}{l}\text { Positive } \\
\text { predictive value }\end{array}$ & $\begin{array}{l}\text { Negative } \\
\text { predictive value }\end{array}$ & $\begin{array}{l}\text { Positive } \\
\text { likelihood ratio }\end{array}$ & $\begin{array}{l}\text { Negative } \\
\text { likelihood ratio }\end{array}$ & Accuracy & $\begin{array}{l}\text { Area under } \\
\text { ROC curve }\end{array}$ & $\mathbf{n}$ \\
\hline 1 & 1.00 & 0.32 & 0.22 & 1.00 & 1.47 & 0.00 & 0.48 & 0.66 & 27 \\
\hline 2 & 1.00 & 0.44 & 0.25 & 1.00 & 1.79 & 0.00 & 0.56 & 0.72 & 27 \\
\hline $3^{*}$ & 1.00 & 0.55 & 0.17 & 1.00 & 2.20 & 0.00 & 0.58 & 0.77 & 12 \\
\hline 4 & 1.00 & 0.32 & 0.22 & 1.00 & 1.47 & 0.00 & 0.48 & 0.66 & 27 \\
\hline $5^{*}$ & 1.00 & 0.13 & 0.07 & 1.00 & 1.14 & 0.00 & 0.18 & 0.56 & 17 \\
\hline 6 & 1.00 & 0.32 & 0.22 & 1.00 & 1.47 & 0.00 & 0.48 & 0.66 & 27 \\
\hline 7 & 1.00 & 0.07 & 0.16 & 1.00 & 1.08 & 0.00 & 0.22 & 0.53 & 27 \\
\hline 8 & 1.00 & 0.00 & 0.15 & 1.00 & 1.00 & 0.00 & 0.15 & 0.50 & 27 \\
\hline 9 & 1.00 & 0.38 & 0.24 & 1.00 & 1.61 & 0.00 & 0.52 & 0.69 & 27 \\
\hline 13 & 0.00 & 0.63 & 0.00 & 0.72 & 0.00 & 1.59 & 0.50 & 0.31 & 20 \\
\hline 14 & 0.50 & 0.50 & 0.20 & 0.80 & 1.00 & 1.00 & 0.50 & 0.50 & 20 \\
\hline 15 & 0.00 & 1.00 & 0.00 & 0.80 & 0.00 & 1.00 & 0.80 & 0.50 & 20 \\
\hline $15^{*}$ & 0.00 & 1.00 & 0.00 & 0.43 & 0.00 & 0.00 & 0.43 & 0.50 & 7 \\
\hline 16 & 0.00 & 1.00 & 0.00 & 0.80 & 0.00 & 1.00 & 0.80 & 0.50 & 20 \\
\hline $16^{*}$ & 0.00 & 1.00 & 0.00 & 0.43 & 0.00 & 0.00 & 0.43 & 0.50 & 7 \\
\hline
\end{tabular}

A cut-off value of partial pressure of arterial oxygen $\left(\mathrm{PaO}_{2}\right) \leq 50 \mathrm{mmHg}$ was used to define positive cases. ${ }^{*}$ Each equation was tested on the full sample as well as the portion of the sample that fit the inclusion criteria of the original author, if applicable. ROC Receiver operating characteristic

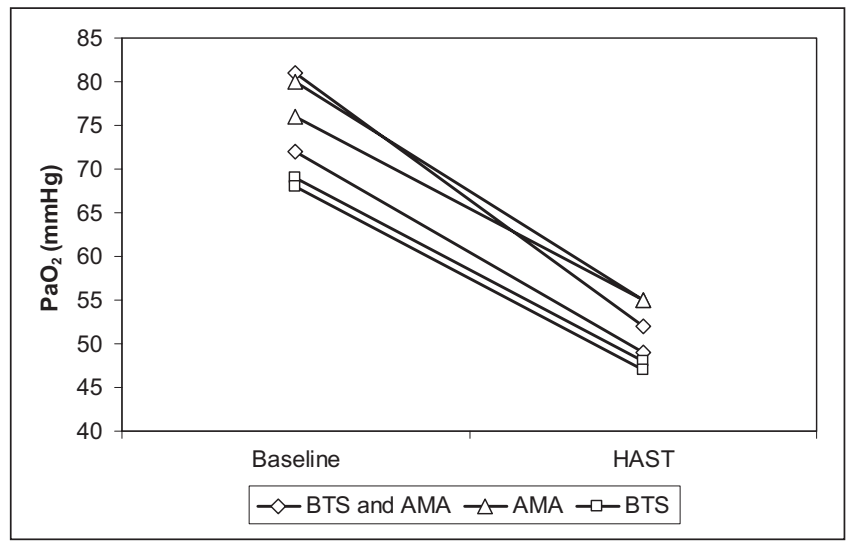

Figure 1) Partial pressure of arterial oxygen $\left(\mathrm{PaO}_{2}\right)$ drop in six patients whom guidelines considered fit to fly. The patients were considered fit to fly by at least one of the criteria set by the British Thoracic Society (BTS; baseline saturation of peripheral oxygen $\left[\mathrm{SpO}_{2}\right]>95 \%$ and the Aerospace Medical Association (AMA; $\mathrm{PaO}_{2}$ at ground level $\geq 70 \mathrm{mmHg}$ ). Three patients had a posthypoxia altitude simulation test (HAST) $\mathrm{PaO}_{2}$ of less than $50 \mathrm{~mm} \mathrm{Hg}$, while the other three subjects had a $\mathrm{PaO}_{2}$ of between $50 \mathrm{mmHg}$ and $55 \mathrm{mmHg}$

After controlling for $\mathrm{PaO}_{2 \mathrm{gr}}$, DLCO remained significantly and independently associated with $\mathrm{PaO}_{2 \text { alt }}(\mathrm{r}=0.60 ; \mathrm{P}<0.04)$, as did $\mathrm{FEV}_{1} \%$ predicted $(\mathrm{r}=-0.48 ; \mathrm{P}<0.04)$. Because the sample size allowed for the examination of two-variable interactions, the following new prediction equations were derived:

$$
\begin{aligned}
& \mathrm{PaO}_{2 \text { alt }}=0.41\left(\mathrm{PaO}_{2 \mathrm{gr}}\right)+0.54(\mathrm{DLCO})+22.08 \\
& \mathrm{PaO}_{2 \text { alt }}=0.34\left(\mathrm{PaO}_{2 \mathrm{gr}}\right)-0.05\left(\mathrm{FEV}_{1} \%\right)+24.22
\end{aligned}
$$

\section{DISCUSSION}

Our data suggest that current guidelines concerning the need for detailed assessment of oxygen requirements at altitude need review. In the patients tested, neither $\mathrm{SpO}_{2}$ or $\mathrm{PaO}_{2 \mathrm{gr}}$ was sufficiently sensitive or specific to determine the patients most in need of altitude simulation or further evaluation. Our results, like those of Christensen et al (16), show that using cut-offs to identify patients who are fit to fly without further examination misses up to one-third of individuals who will desaturate to a $\mathrm{PaO}_{2}$ of less than $50 \mathrm{mmHg}$. Furthermore, equations are poor predictors of $\mathrm{PaO}_{2}$ measured during altitude simulation procedures and, thus, are an unreliable means of determining a patient's fitness to fly. Because no individual equation could consistently distinguish patients who needed oxygen from those who did not, we recommend against their use in preflight evaluation. Concern over this practice has been raised previously by authors reporting poor reproducibility of results $(17-20)$. These equations have been accepted as interchangeable with other methods, despite the lack of validation. We suggest that the HAST should be used to evaluate all patients suspected to be at risk of becoming hypoxemic at altitude. Using the equations as a criteria for HAST selection is also a risky practice because our results showed that their predictions depended largely on which equation was used rather than on patient characteristics.

We demonstrated a correlation between $\mathrm{FEV}_{1}$ and $\mathrm{PaO}_{2 \text { alt }}$. This second-order correlation has been reported several times $(6,10,15)$ but the finding has not been consistently reproduced (21). Interestingly, our study suggests that DLCO and $\mathrm{FEV}_{1}$ are better predictors of $\mathrm{PaO}_{2 \text { alt }}$ than $\mathrm{PaO}_{2 \mathrm{gr}}$. This finding is consistent with the predictors of arterial desaturation in COPD patients during exercise (22). 


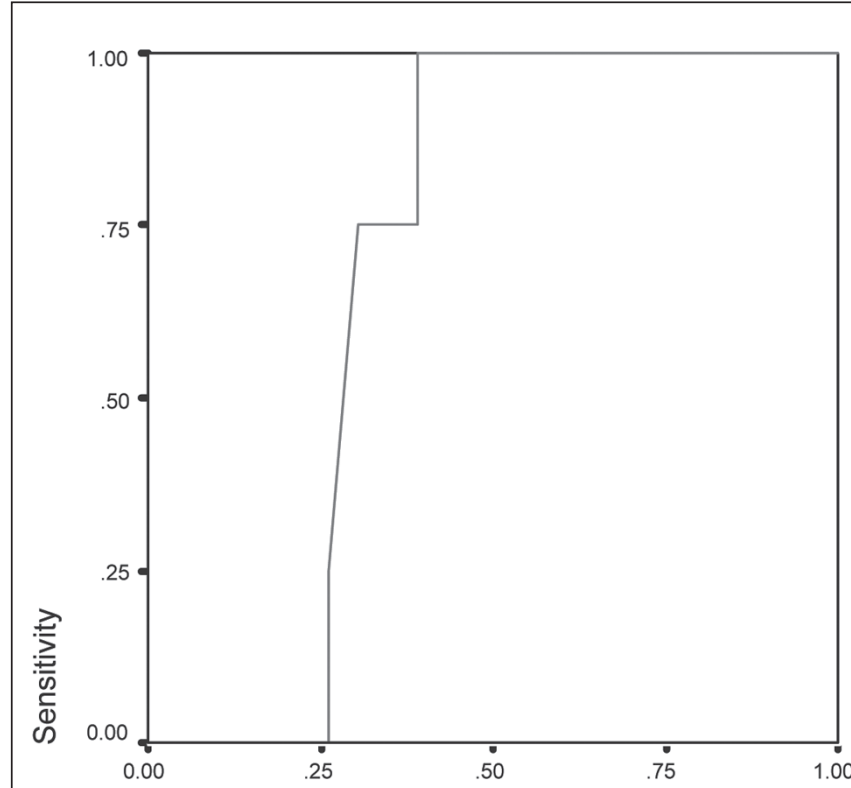

A 1 - Specificity

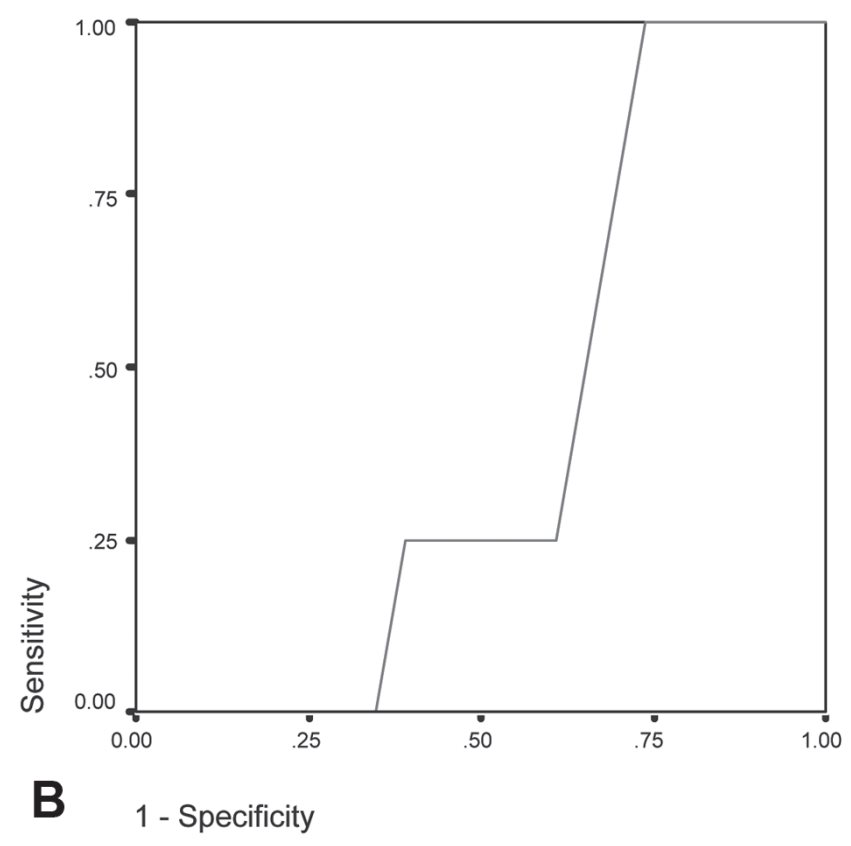

Figure 2) Receiver operating characteristic (ROC) analysis of baseline partial pressure of arterial oxygen ( $\left.\mathrm{PaO} \mathrm{O}_{2}\right)$ and resting baseline saturation of peripheral oxygen $\left(\mathrm{SpO}_{2}\right)$ related to the hypoxia altitiude simulation test (HAST) outcome $(n=27)$. (A) $\mathrm{ROC}_{\text {curve of } \mathrm{PaO}}$ at ground level and HAST outcome gave an area under the curve of $0.696(\mathrm{P}=0.13)$. At a specificity of $100, \mathrm{PaO}_{2} \leq 72 \mathrm{mmHg}$. (B) $\mathrm{ROC}$ analysis of SpO 2 at rest related to HAST outcome, gave an area under the curve of 0.402 and a $\mathrm{SpO}_{2}$ cut-off for recommending a HAST of $95 \%$ or lower

We also found the $50 \mathrm{~m}$ walk test to be an unreliable predictor of fitness to fly because all of the evaluated patients who had available walk test data greatly exceeded this distance. We did find, however, that the patients in our pool who walked $330 \mathrm{~m}$ or less during the 6 min walk test all had a $\mathrm{PaO}_{2}$ of less than $50 \mathrm{mmHg}$ after the HAST.

Several questions remain regarding the generalizability of the HAST results. Because the simulation lasts only $20 \mathrm{~min}$, it is unclear whether a further drop in $\mathrm{PaO}_{2}$ can be expected on longer flights. While there is some evidence that this does not occur, patients may compensate for the reduced oxygen by increasing their respiratory rate (18). This could possibly become fatiguing in longer flights, resulting in a delayed decrease in respiratory rate and, consequently, a further drop in $\mathrm{PaO}_{2}$.

There is a need for more evidence on which to base guidelines in this field. Current guidelines vary, and among individual clinicians, the practice is even more diverse (23). For example, $\mathrm{PaO}_{2}$ in flight is considered safe if it is greater than $50 \mathrm{mmHg}$. This value was reported in the paper that first described the HAST test (11), and was subsequently incorporated into guideline documents and other publications $(1,6,17,24,25)$. We find this value to be substantially lower than necessary, and speculate that patients with a $\mathrm{PaO}_{2}$ of between $50 \mathrm{mmHg}$ and $55 \mathrm{mmHg}$ may also benefit from inflight oxygen.

Our ROC analysis of $\mathrm{PaO}_{2}$ and $\mathrm{SpO}_{2}$ criteria for HAST produced mixed results. Although both cut-offs coincided with guidelines, these findings were not statistically significant, and the areas under the ROC curves indicated poor predictive ability of these variables. We suggest more analyses such as these be performed to form a solid evidence base from which to draw guidelines.
Some limitations to our study must be noted. First, our sample size was small, reflecting the infrequent use of altitude simulation procedures to assess fitness to fly. We doubt that a larger sample size would significantly alter our major conclusions given the poor performance of screening recommendations and predictive equations. Second, our patients' referral for this test indicates they were at a geographical advantage and had time to perform the test before travel; consequently, their results may only approximate those of the larger population. Although it is possible that they were at particular risk of hypoxemia in flight, this was not evident from any demographic, clinical or physiological characteristics at baseline, and the population was sufficiently diverse in HAST outcome to test the screening recommendation and predictive equations. Third, although the HAST is the gold standard for estimating in-flight hypoxia, it does not take into account the effects of additional stress and exercise performed at altitude. Finally, our population was not limited to patients with COPD but also included patients with restrictive processes. However, when these were excluded, our conclusions remained unchanged. Avenues for future research include consideration of underlying pulmonary diagnosis as a baseline variable in the clinical outcomes among disease entities, and the implications of increasing the use of the HAST from a cost perspective.

\section{SUMMARY}

Current screening recommendations do not identify all patients at significant risk for hypoxemia at altitude and predictive equations based on ground level variables cannot replace altitude simulation procedures when evaluating patient need for oxygen supplementation during airline flight. 
ACKNOWLEDGEMENTS: The authors thank Emilio Perri, Myra Slutsky and Eva Leek for their administrative and technical assistance, and Edmee Franssen for her statistical advice. This research was supported, in part, by the Imperial Oil Foundation.

\section{REFERENCES}

1. Managing passengers with respiratory disease planning air travel: British Thoracic Society recommendations. Thorax 2002;57:289-304.

2. American Thoracic Society/European Respiratory Society Task Force. Standards for the Diagnosis and Management of Patients with COPD (2004) < http://www.thoracic.org/go/copd> (Version current at October 13, 2006).

3. Lien D, Turner M. Recommendations for patients with chronic respiratory disease considering air travel: A statement from the Canadian Thoracic Society. Can Respir J 1998;5:95-100.

4. Medical guidelines for airline travel, 2nd edn. Aviat Space Environ Med 2003;74(Suppl 5):A1-19.

5. Department of Veterans Affairs, Department of Defense. VA/DoD Clinical Practice Guideline for Management of Outpatient Chronic Obstructive Pulmonary Disease. Department of Veterans Affairs, Washington DC, 2007.

6. Dillard TA, Moores LK, Bilello KL, Phillips YY. The preflight evaluation. A comparison of the hypoxia inhalation test with hypobaric exposure. Chest 1995;107:352-7.

7. Naughton MT, Rochford PD, Pretto JJ, Pierce RJ, Cain NF, Irving LB. Is normobaric simulation of hypobaric hypoxia accurate in chronic airflow limitation? Am J Respir Crit Care Med 1995;152(6 Pt 1):1956-60.

8. Kelly PT, Swanney MP, Seccombe LM, Frampton C, Peters MJ, Beckert L. Air travel hypoxemia vs. the hypoxia inhalation test in passengers with COPD. Chest 2008;133:920-6.

9. Kelly PT, Swanney MP, Frampton C, Seccombe LM, Peters MJ, Beckert LE. Normobaric hypoxia inhalation test vs. response to airline flight in healthy passengers. Aviat Space Environ Med 2006;77:1143-7.

10. Dillard TA, Berg BW, Rajagopal KR, Dooley JW, Mehm WJ. Hypoxemia during air travel in patients with chronic obstructive pulmonary disease. Ann Intern Med 1989 1;111:362-7.

11. Gong H Jr, Tashkin DP, Lee EY, Simmons MS. Hypoxia-altitude simulation test. Evaluation of patients with chronic airway obstruction. Am Rev Respir Dis 1984;130:980-6.
12. Henry JN, Krenis LJ, Cutting RT. Hypoxemia during aeromedical evacuation. Surg Gynecol Obstet 1973;136:49-53.

13. Seccombe LM, Kelly PT, Wong CK, Rogers PG, Lim S, Peters MJ. Effect of simulated commercial flight on oxygenation in patients with interstitial lung disease and chronic obstructive pulmonary disease. Thorax 2004;59:966-70.

14. Muhm JM. Predicted arterial oxygenation at commercial aircraft cabin altitudes. Aviat Space Environ Med 2004;75:905-12.

15. Dillard TA, Rosenberg AP, Berg BW. Hypoxemia during altitude exposure. A meta-analysis of chronic obstructive pulmonary disease. Chest 1993;103:422-5.

16. Christensen CC, Ryg M, Refvem OK, Skjonsberg OH. Development of severe hypoxaemia in chronic obstructive pulmonary disease patients at 2,438 $\mathrm{m}(8,000 \mathrm{ft})$ altitude. Eur Respir J 2000;15:635-9.

17. Johnson AO. Chronic obstructive pulmonary disease: Fitness to fly with COPD. Thorax 2003;58:729-32.

18. Akero A, Christensen CC, Edvardsen A, Skjonsberg OH. Hypoxaemia in chronic obstructive pulmonary disease patients during a commercial flight. Eur Respir J 2005;25:725-30.

19. Christensen CC, Ryg MS, Refvem OK, Skjonsberg OH. Effect of hypobaric hypoxia on blood gases in patients with restrictive lung disease. Eur Respir J 2002;20:300-5.

20. Martin SE, Bradley JM, Buick JB, Bradbury I, Elborn JS. Flight assessment in patients with respiratory disease: Hypoxic challenge testing vs. predictive equations. QJM 2007;100:361-7.

21. Robson AG, Hartung TK, Innes JA. Laboratory assessment of fitness to fly in patients with lung disease: A practical approach. Eur Respir J 2000;16:214-9.

22. Owens GR, Rogers RM, Pennock BE, Levin D. The diffusing capacity as a predictor of arterial oxygen desaturation during exercise in patients with chronic obstructive pulmonary disease. N Engl J Med 1984 10;310:1218-21.

23. Coker RK, Partridge MR. Assessing the risk of hypoxia in flight: The need for more rational guidelines. Eur Respir J 2000;15:128-30.

24. Celli BR, MacNee W. Standards for the diagnosis and treatment of patients with COPD: A summary of the ATS/ERS position paper. Eur Respir J 2004;23:932-46.

25. Gong H Jr. Advising patients with pulmonary diseases on air travel. Ann Intern Med 1989 1;111:349-51. 


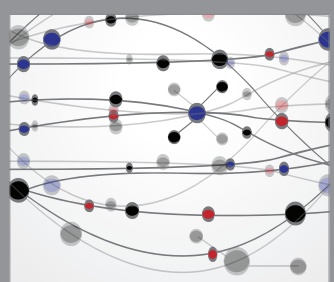

The Scientific World Journal
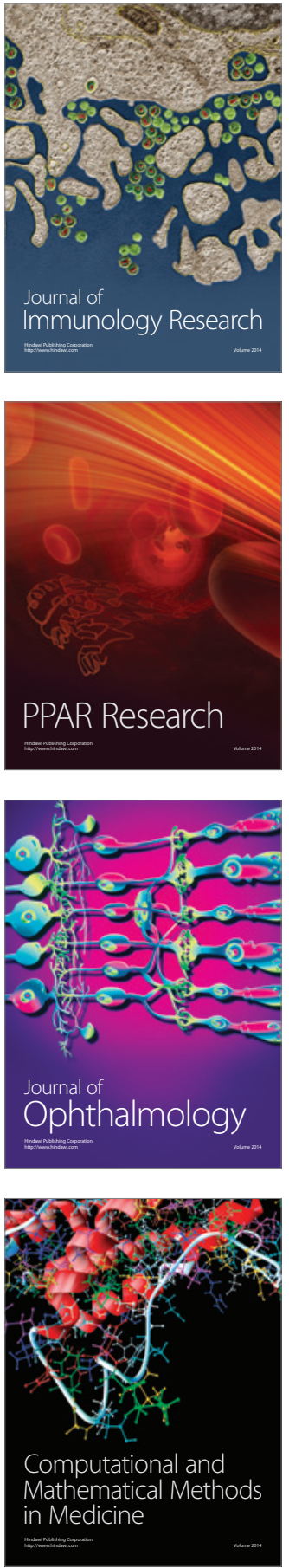

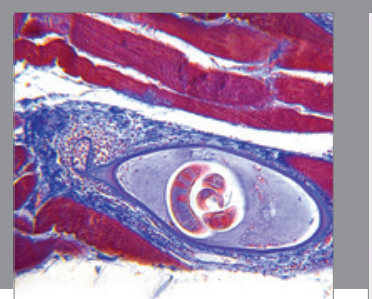

Gastroenterology Research and Practice

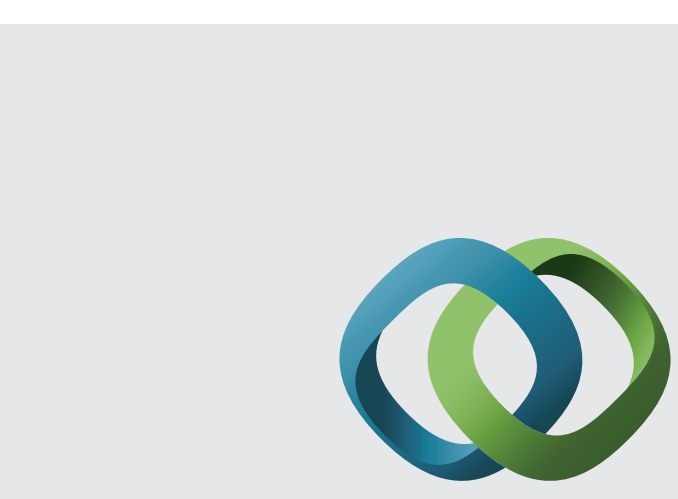

\section{Hindawi}

Submit your manuscripts at

http://www.hindawi.com
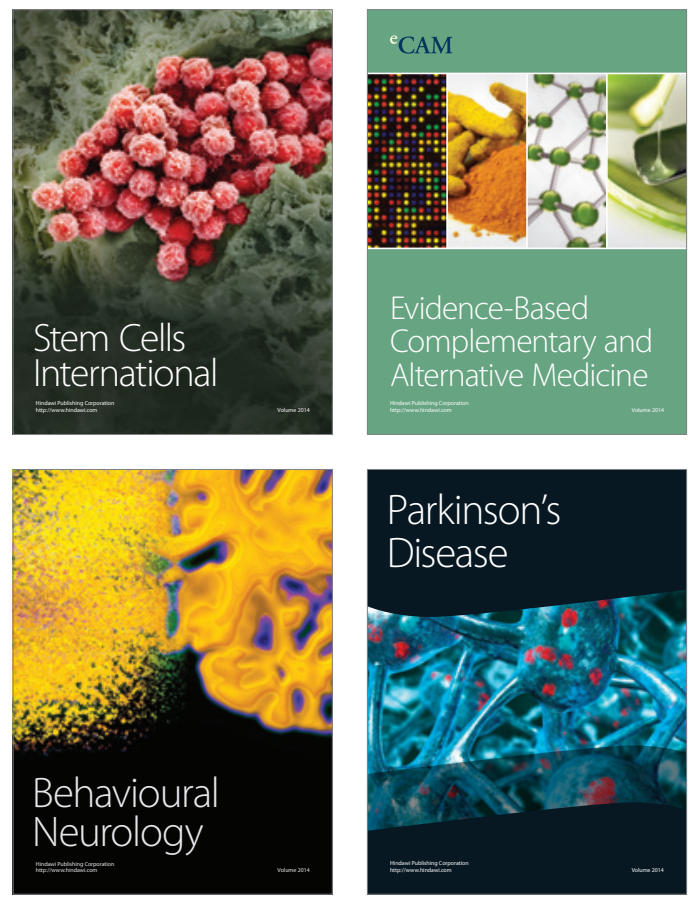
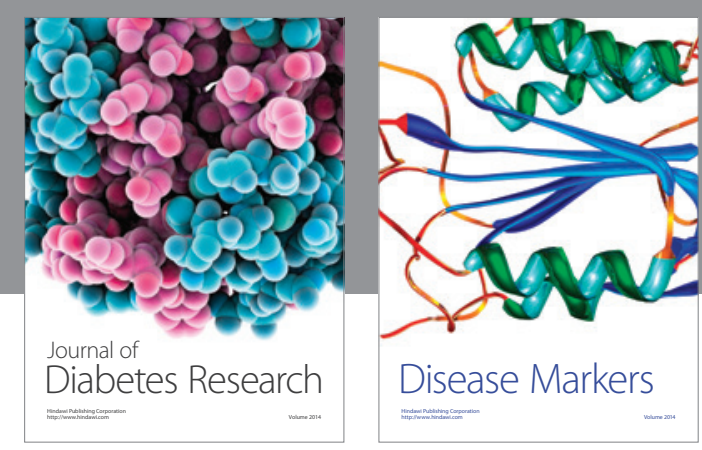

Disease Markers
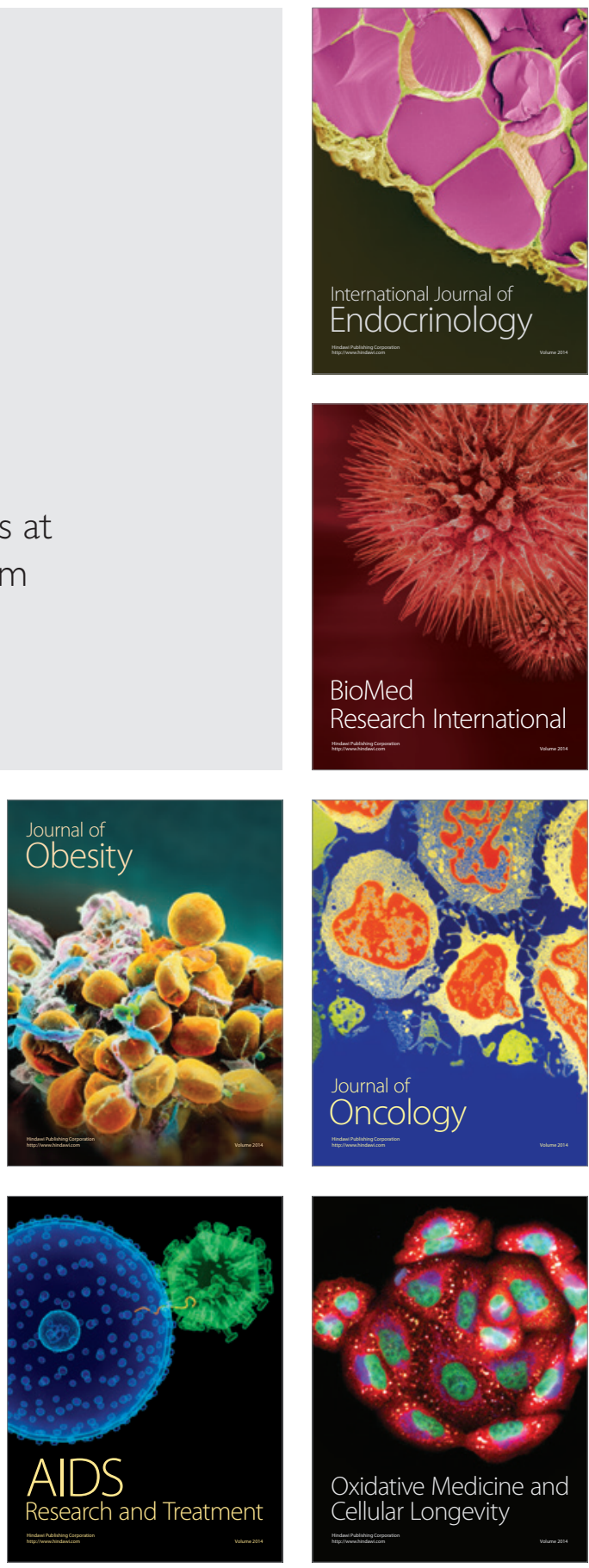